\title{
TRANSFORMATION AND INTERPRETATION OF GENDER CONCEPTS IN METAPHYSICAL DIMENSION: FROM CONTEMPLATIVE WORLDVIEW TO TRANSPERSONAL EXPERIENCE
}

\author{
Andrii Bezrukov
}

Ph.D., Philology and Translation Department, Dnipro National University of Railway Transport named after

Academician V. Lazarian, Ukraine.

Email: dronnyy@gmail.com

Article History: Received on $1^{\text {st }}$ May 2020, Revised on $25^{\text {th }}$ June 2020, Published on $1^{\text {st }}$ August 2020

\begin{abstract}
Purpose of the study: Verbalization of concepts in the artistic dimension is of great significance in the study of the metaphysical view of the world. This study is undertaken to identify and describe the principal ways of transformation and interpretation of verbalized concepts with gender features, in particular the concept of WOMAN, in the poetic discourse of the Metaphysicals.
\end{abstract}

Methodology: It is based on the combination of research strategies of an interdisciplinary approach with the methods of interpretive, linguistic-stylistic, hermeneutic, and imagological analysis. Adopting the methods of interpretive analysis of literary writings in the gender dimension allows us to greatly broaden the applicable scope of them.

Main findings: Gender concepts analysis based on the seventeenth-century English metaphysical poetry can be of great importance since the functioning and transformation of the sphere of concepts are complicated by metaphorical, symbolic, and linguistic ambivalence - an essential element of artistic practices of the Metaphysicals. Verbalization of the concepts of MAN and WOMAN actualise a particular way of transforming and conveying the basic features of the conceptual system of gender through the lens of dialectical thinking.

Application of the study: The analysis of gender concepts in poetry appears to be an embranchment of relevant and influential gender studies contributing to such fields of humanities as literary studies, linguistics, and philosophy, cultural and religious studies. This emphasizes an interdisciplinary/multidisciplinary approach.

Novelty/Originality: The means of interpretive analysis help achieve objectification of the gender sphere of concepts in the metaphysical dimension that becomes a crucial means of representation of the linguistic worldview. Since the verbalization of gender concepts and gender considerations in the poetry of the Metaphysicals, and especially in John Donne's, is not always explicit, the study of them at the imagery level allows revealing even implicit concepts, in particular gender ones, arising from mental activity, spiritual life, and transpersonal experience. In metaphysical poetry, the word is considered a means of contemplating reality and transcending beyond it.

Keywords: Gender, Woman, Metaphysicals, Concept, Transpersonal, Poetry, Transformation.

\section{INTRODUCTION}

Axiological parameters and ideas as to the place and role of a man and woman in the world's gender view and related social and stereotypical opinions are regulated at the level of mental activity, systematized in the form of concepts where gender is a central element of the polarization of cultural, psychological and social phenomena in the mind and language. It is evident that the principal concepts among the gender ones are concepts of MAN and WOMAN, although the inflexibility of this binary opposition has recently been called into question (Vlasova, 2015).

Studying a gender perspective in the linguocultural (or even in linguistic) dimension involves the inclusion in the analysis of a particular discourse inherently integrated into the culture since it comprises the interpretation of texts written into the social context (Marotti, 2006). The most revealing in terms of interpreting gender concepts and transforming their forms and meanings is a poetic discourse. The seventeenth-century English metaphysical poetry, which focuses primarily on two objects - the God and the Woman, can be a preferable source of literary material for the following reasons.

On the first hand, if gender is considered a purely philosophical category that correlates with the concept of an ontological basis, then metaphysical poetry is widely the part of philosophical poetry that goes beyond the physical understanding of the world and is associated with the transpersonal experience, the discovery of supernatural sources of existence (Teskey, 2019; Sullivan, 2008). The expression of this experience in poetic form is actualised through conceptual eclecticism based on the use of the intricate metaphysical concepts (Riano, 2019).

On the other hand, if the type of the worldview in a work of art and the type of the character are interdependent (Lotman, 1998), then in the artistic world of metaphysical poetry, the female character is at the forefront. It is an essential object of imagery. The author's associations seem to be connected with it; it mostly alters the worldview and reflects the specificity of the poet's ideological principles; the woman plays a significant role in the communicative structure of works, being, as already mentioned, the primary addressee of the author. It seems in The Songs and Sonnets (1635) by John Donne (1572-1631), an inspirational poet of the metaphysical school in England. Donne's poetry is 
obsessed with women (Bell, 2006; Mintz, 2001). At the same time, the woman in metaphysical poetry is a puzzle. She is both the temptress and divine perfection; loyal and fickle.

To comprehend the features of the gender concepts functioning in Donne's works, it is necessary to determine the gender situation developed during the period of the activity of the poet, at the beginning of the seventeenth century (Hammons, 2010; Bell, 2010; Benet, 1994). It is significant that Laqueur (2003) asserts seventeenth-century conceptions of gender to be bound up with a one-sex model of human physiology. In this case, the male and female bodies' anatomical similarity required elaborate discursive and educational codes to stabilize difference. Similar ideas can be found in the study of Breitenberg (1996) who claims that early modern male writers "stage masculine loss and vulnerability for the purpose of maintaining control of the performance of one's gendered identity", inferring that the very conceptual ambiguity that allows for Donne's poetic "inversions" of gender might also be what produces a rhetoric of cementing difference (p. 6). Nonetheless, in Donne's verses, the woman appeared to be a crucial subject and a reader as well (Mueller, 1989, p. 142).

Grady (2017) emphasizes that Donne's poems are that either celebrate masculine sexual pleasure in the contexts where the female sexual partner is merely an object and/or a conquest, which claim with a variety of affects that true mutual love is an impossibility, or that express memorable recrimination (bitter, funny, or both) against the particular woman or women in general - usually because of their alleged promiscuity and inconstancy or disdain for the poetic speaker (p. 103).

Gender is a complex component of the early modern social imaginary (Wade, 2014; Hammons, 2010; Bates, 2007; Saunders, 2006). Gender matters are embodied in the works of the time, actualising the Baroque poetics which emphasizes a keen understanding of the world by the authors. Keeping this mind the author of the article to identify and describe the principal ways of transformation and interpretation of verbalized concepts with gender features in the poetic discourse of the Metaphysicals.

\section{LITERATURE REVIEW}

The seventeenth-century English metaphysical poetry seems to be an original phenomenon distinguished by the intellectual basis; the appeal to the reader's mind and imagination but not feelings and emotions; wit enabling one to bring in verses non-poetic concepts ( $\mathrm{Li} \& \mathrm{Ce}$, 2019; Bednarz, 2012); poets' immersion in the Christian religious philosophy that became the basis for the presentation of their ideas as to the origins of the world (Teskey, 2019;

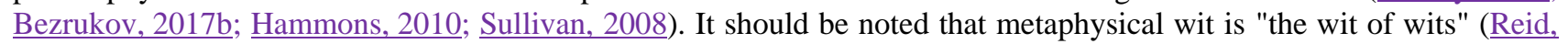
2000, p. 6).

John Donne's life and creative career have repeatedly been the focus of literary studies. But there are not so many scholarly papers that consider all the aspects of functioning gender as a philosophical category in metaphysical poetry, in particular in Donne's poems, and the embodiment of the concepts in the allegorical outline of the Metaphysicals' works.

Some scholars believe that the fundamental concept of WOMAN in metaphysical poetry should be considered as its principal idea. Donne often uses women as an object for the subject of his poetry and seems obsessed with women whose liking for them is merely for the joy of his poetry. The poet's private utterance of action in the physical aspects of lovemaking and intimacy uses women as an object (Sarangi, 2013).

This actualises the theory of male subjectivity that subordinates issues of desire beneath the historical imperatives which inform those desires. According to Barnes (2009), in early modern England, John Donne and some other Metaphysicals created an ideology of masculinity to respond to the great epistemological upheavals of the epoch. Donne and the Metaphysicals contributed to the creation of a kind of masculinity embodying an ironic subject position that is constantly shifting between men's desires for women and men's simultaneous rejection of women's bodies.

Bates (2007) takes a slightly different view in her book Masculinity, Gender, and Identity in the English Renaissance Lyric. It deals with the male poet or lover who often appears not as powerful and masterly but rather as broken, abject, and feminine in early modern lyric poetry. Focusing on John Donne, Phillip Sidney, William Shakespeare, and Walter Ralegh, and taking direction from psychoanalytic theories of gender formation, Bates represents critical strategies to comprehend and appreciate what is genuinely revolutionary about their texts. Existing critical approaches have a marked impact on the figure of the authoritative male writer.

Thommen (2014) reviews how John Donne incorporates sexual imagery into the religious context and spiritual experience. The author's perspectives on the events and things of life are mainly based on the poet's ideas about the ecstatic state. Donne collides with the postulates and beliefs of some ancient Greek schools of thought (e.g., the Stoics), which considered sensual experiences to be disfavoured compared to the power of order and reason in discovering spiritual truth.

In John Donne, Body and Soul, Targoff (2008) insists on revising Donne's works and considers him to be the author who devoted himself to a great subject connected with his deepest emotional and intellectual problems. She convincingly shows that Donne believed throughout his life in the mutual necessity of body and soul. The obsessive imagination of both a natural union and the inevitable separation between body and soul is the conceptual idea of Donne's poetry. 
It is worthy of note that Grady (2017) calls John Donne one of the most controversial poets in the history of English literature, maintaining that his intellectualism and complexity provoking both praise and censure. Grady argues that Donne's works can be reappraised nowadays through Walter Benjamin's theory of Baroque allegory. This study reveals Donne as being immersed in the aesthetic of fragmentation that defines the Baroque style. Without reference to Grady, it seems the issue of how the discussion of the Baroque is figuring in contemporary Donne studies is narrowly construed.

According to Bell (2006), Donne in gender matters is sincere, passionate, and disturbing. He is continually touching women and gender roles, both explicitly and indirectly, through analogy and metaphor in his works. But the concept of WOMAN in Donne's poems is being transformed, and women are rather the reflection of male desires, a kind of metaphor for the poet's professional aspirations.

Mintz (2001) nevertheless suggests that the genderedness of Donne's poetic imagination is not as emphatically, certainly not as consistently, "masculine", or masculinist, as has so often been claimed (p. 603).

Saunders (2006) reevaluates Donne's poetry, demonstrating "the dialectic of desire". For his research, Saunders involves the theories of historicism, feminism, queer theory, and methods of postmodern psychoanalysis, thereby expressing the complexity and ambiguity of Donne's attitude to the world and women in particular. DiPasquale (2011) considers many of Donne's sonnets as lectures on women and sex.

Although there are some papers on the subject, in the gender dimension, this issue is studied insufficiently. One of the main reasons for those mentioned above is that the experience of the intensive spiritual life of J. Donne and the Metaphysicals, as reflected in their works, explicitly does not always include the verbalization of gender concepts. Anyway, a word is a key to discovering a concept as a unit of mental activity (Popova \& Sternin, 2015). At the same time, the interpretative analysis of the gender conceptual field of English metaphysical poetry specifically seems to be relevant, since the functioning and transformation of the spheres of concepts which have a certain associative orientations get complicated by the problem of metaphorical, symbolic, and general linguistic ambivalence - an essential element of the metaphysical worldview.

Transformation of the metaphysical worldview from contemplating reality to transpersonal experiencing is expressed in the works of the Metaphysicals. This shift can be explained by a particular position of the poets of the metaphysical school. The transpersonal which means the suprapersonal essence of human consciousness (Bond, 2019; Netzer, 2015) is of great significance in metaphysical poetry since it is relevant to the very notion of the metaphysical - the supersubstantial essence of being.

The idea of the contemplative vision of the world is rooted in the Christian tradition of the contemplative worldview which helps us see ourselves as "pilgrims and strangers" in this world (Cavazos-González, 2010, p. 94). This tradition involves the contemplative practice of being mindful of the sacrament or sacredness of the present moment (Blanton, 2019). This way of contemplating the world allows the metaphysical poets to include to the poems their ideas as to the sacred origins of the universe and metaphorically depict their views concerning the position of the woman and God in our lives. Such a kind of poetry finds its authority in metaphysics authenticated by the individual imagination (Bond, 2015).

Dörge (2018) insists on the particular importance of the notion of transformation in metaphysical poetry. She denotes these transformations as the diverse kinds of turning and classifies them as follows: a turn to God (religious conversion), turning as a requisite for harmony (musical tuning), turning in space (spatial movement), turning from one kind into another (divine transformation), and circular turning.

\section{METHODOLOGY}

Methodology in the paper is based on the combination of research strategies of an interdisciplinary/multidisciplinary approach with the methods of interpretive, linguistic-stylistic, hermeneutic, and imagological analysis in studying interpretation and transformation of gender concepts in the metaphysical dimension.

Adopting the method of interpretive analysis of literary writings in the other types of spiritual activity, philosophy in general, and gender studies, in particular, allows us to greatly broaden the applicable scope of them. Also, the conceptual analysis of metaphysical poetry in the gender dimension, while being the study of metaphorical and semantic ambivalence, appears in the paper to be a principal means of representing the linguistic worldview in its historical, cultural, and national specifics. And verbalization of the mental concepts of MAN and WOMAN at the imagery level objective a particular way of transferring the essential elements of the conceptual system of gender.

Since the verbalization of gender concepts and gender considerations in the poetry of the Metaphysicals, and in particular in Donne's (Stubbs, 2008), is not always explicit, the study of them at the imagery level allows seeing even implicit concepts, in particular gender ones, arising from the mental activity. At the same time, the application of the methods of interpretative analysis of the literary material in philosophy and gender studies broadens their potencies, and the verbalization of the concepts of MAN and WOMAN actualise a particular way of transforming and conveying the principal elements of the conceptual system of gender. 


\section{RESULTS, ANALYSIS \& DISCUSSION}

\section{Conceptualizing the Woman and God in the metaphysical worldview}

Studying the gender concepts in Donne's poetry should be started from verses that open The Songs and Sonnets, as the composition of the Metaphysicals' collections of poems is known to have never been random, but always subject to clear rules for the arranging of poetic material to influence a reader. The sophisticated interpretation and realization of the woman can be found in one of the first poems of The Songs and Sonnets, The Flea. Donne uses the creative technique of the animalistic representation of the beautiful through the ugly, using the metaphysical conceit (Cohen, 2002). The poet metaphorically redefined the motif rather common in the sixteenth-century erotic poetry. The figure of a flea, which bites the beloved woman, borrowed from the Renaissance poetry (Filo, 2019), where it was trendy, and in the axiological hierarchy of insect imagery, it was usually in the field of aesthetic modality. This imagery symbolized the passion of the character, which either sought to turn into a flea and thus gain access to the beloved's desired body, or perish, like a flea, from the hand of the one he loves, on her bosom. However, Donne actualises this motif with the metaphysical wit, the imagination of the poet makes the flea bite not only the girl but also the man, making the annoying insect their "marriage bed", "marriage temple" with living walls where they could hide from any prohibitions, and finally a symbol of their sexual union:

Marke but this flea, and market in this, // How little that which thou deny' st me is; // It suck'd me first, and now sucks thee, // And in this flea our two bloods mingled bee; // Thou know' st that this cannot be said // A sinne, nor shame, nor loss of maidenhead // Yet this enjoys before it wooe, // And pamper'd swells with one blood made of two, // And this, alas, is more than wee would doe. (Booth, 2002, p. 26)

Baroque imbalance and the desire for harmony are the most characteristic features for The Songs and Sonnets. The character of the metaphysical poems, having lost his inner world, seeks the truth, and finds it in the joys of mutual love. In Donne's verses, the search for emotional balance is accompanied by psychological tension. In A Feaver the character begs his beloved not to die, and the effect of mental stress is achieved through the enamoured's tragic associations about the probable death of his woman. Although Donne combines the notion of death with the notion of love (Bauer \& Zirker, 2013), the character perceives his woman's death as a world catastrophe, the collapse of the universe. The combination of micro- and macrocosm appears in the tragic context: the woman represents a whole world that will disappear along with her:

Oh doe not die, for I shall hate // All women so, when thou art gone, // That thee I shall not celebrate, // When I remember, thou wast one. // But yet thou canst not die, I know; // To leave this world behind, is death; // But when thou from this world wilt goe, // The whole world vapors with thy breath. // Or if, when thou, the worlds soule, goest, // It stay, tis but thy cakasse then; // The fairest woman, but thy ghost, // But corrupt worms, the worthiest men. (Booth, 2002, p. 11)

It is noteworthy that the ambivalence of the real and surreal which is traditional for Baroque poetry (Hudson, 2019; Lambert, 2004) plays a key role in The Songs and Sonnets. Donne almost wholly removes the boundaries between reality and dreams, illusions and real life. In the poem The Dreame, the woman appears in the form of a supernatural creature capable of penetrating the mind and moving from the real world to the ideal one:

Deare love, for nothing lesse than thee // Would I have broke this happy dreame, // It was a theme // For reason, much too strong for phantasie, // Therefore thou wakd' st me wisely; yet // My Dreame thou brok' st not, but continued' st it. // Thou art so truth, that thoughts of thee suffice, // To make dreames truths; and fables histories; // Enter these armes, for since thou thoughtst it best, // Not to dreame all my dreame, let's act the rest. // As lightning, or a Taper's light, // Thine eyes, and not thy noise wak'd me; // Yet I thought thee // (For thou lovest truth) an Angell, at first sight; // But when I saw thou sawest my heart, // And knew' st my thoughts, beyond an Angell's art, // When thou knew' st what I dreamt, when thou knew' st when // Excesse of joy would wake me, and cam' st then, // I must confesse, it could not chuse but bee // Prophane, to thinke thee any thing but thee. (Booth, 2002, p. 24)

The Dreame serves as a further proof that the artists of the Baroque always look towards another world (Lambert, 2004; Harbison, 2000), because earthly life is only a moment, full of suffering, loneliness, a sense of transience and futility, undoubtedly followed by eternity. This dualism in matters of the spirit and body, which was trendy in the Middle Ages, is a crucial feature of The Songs and Sonnets. At the same time, the body is not rejected entirely, as in the Middle Ages, and earthly love is not perceived as a way to God, as in Dante's works. A noteworthy detail is that sometimes Donne demolishes gender discrimination of the male body and female body on biological or psychological levels, as in The Anniversaries (Ahmed \& Wahab, 2017, p. 665).

Donne determines the problem of correlating the soul and body, the otherworldly and earthly in the metaphysical dimension. In The Songs and Sonnets, the matter of the correlation of the spiritual and the sensual is revealed in the conceptual interpretation of the theme of love as a dualistic alliance, that is demonstrated in The Ecstasie, one of the 
most famous Donne's poems, in which the poet describes how the souls of two lovers leave their bodies during their physical union and mix before returning to their bodies. This experience purifies each of the lovers and grants them spiritual fulfillment (Thommen, 2014). According to the medieval mystical concept, the ecstasy is a trans-like state when the soul leaves the body to communicate with the Divine. In Christianity, it also denotes the state of mystical/spiritual communication with God. Donne deliberately - starting with the title - uses an ambivalent term with religious, philosophical, and erotic connotations to build his theory of love (Bezrukov, 2017a; Thommen, 2014).

Ellrodt (Redpath, 2009) and Legouis (1962), who called The Ecstasie "a poem of seduction", supposed that the last stanzas of the poem (lines 49-76) referred to the bodies' association just after higher ecstasy:

But $\mathrm{O}$ alas, so long, so farre, // Our bodies why doe wee forbear? // They Are ours, though they're not wee. Wee are // The intelligences, they the sphere. // <.. > // On man heavens influence workers not so, // But that it first imprints the ayre; // Soe soule into the soule may flow, // Though it to body first repaire. // <..> // To'our bodies turne wee then, that so // Weake men on love reveal'd may looke; // Loves mysteries in soules doe grow, // But yet the body is his booke. (Booth, 2002, p. 35)

But Donne emphasizes the spiritual love is prime. Formed of two souls ("Of what we are compos'd, and made, // For, th'Atomies of which we grow" (Booth, 2002, p. 35)), the new, ultimate one is purified from the natural imperfection of a man, and therefore the souls return to the bodies precisely to convey a new mission learned in a state of ecstatic unity, or, as Gardner (1965) wrote, to "reanimate" them (p. 262).

In The Ecstasie, Donne does not agree with the concept of Neo-Platonists who were inclined to give the body, which lies at the creative core of his works (Greteman, 2010), only the role of a specific shell, where the soul entered and being gained physical properties during passage through the celestial spheres. However, Pound (1991) suggested the interpretation of The Ecstasie close to theirs. But the poet equates in their meanings the categories of physicality and spirituality, demonstrating that it is only through the combination of the opposite, it is possible to attain the Supreme love. Hutton (1994) considers the poetry is most metaphysical, in the philosophical sense, when it is most Platonic.

This is a pivotal tenet of the metaphysical worldview to consider the value of the arts from a scriptural understanding of divine transcendence over and above the philosophical categories the scholars see as dominating Christian theology (Begbie, 2018). It seems quite natural since it is in Donne's poetry, the dramatic transition from the humanism of the Renaissance to the theological conception of the world (Young, 2009), to the religious outlook of the seventeenth century is clearly marked.

In Donne's works, the concept of WOMAN becomes a principal concept which, being transformed through the author's associations. It reflects the specificity of the ideological principles of the poet, and it is the essential component of the communicative structure of his poetry. Accentualisation of metaphysical poetry is carried out with the help of verbalized concepts with gender features, based on the idea of appealing to the concept of WOMAN.

\section{Verbalization and transformation of gender concepts}

The features of the communicative structure and subject/object relations in The Songs and Sonnets can be of great interest. The Baroque tradition dictates the specifics of the lyrical subject of the poems: the character is continually transformed, changing his "face" (Hudson, 2019). He appears to be an unfortunate lover who suffers from the indifference of a woman, a cynic who sings praises of free love, or the half of a happy union of lovers, or a sceptic disappointed in women. Moreover, several verses of The Songs and Sonnets were written from the woman's point of view. They are thematically close to the poems in which the lyrical subject is a man, but the events are depicted from a purely female perspective. It should be added that the addressee, explicitly or implicitly expressed in the texts of The Songs and Sonnets, can be not only a woman but also a particular object of language, an abstract phenomenon - love. Donne's attitude to gender, love, and death and even to religion is traceable through the poet's Self-consciousness (Ellrodt, 2000; Hodgson, 1999).

The subject/object relations in The Songs and Sonnets also create a whole range of relationships between a man and woman with the variation of gender vectors, which, depending on the type of love, change the position of the characters. On the one hand, the beloved appears to be an unapproachable beauty who destroys the character with indifference, on the other hand, a sexual object towards which the erotic pursuit of a man is directed. However, the foreground is a specific type of relationship between a man and a woman when the boundaries of the personal space are erased, and they dissolve in each other.

The following remark of Targoff (2008) appears to be provocative in this context. She insists that Donne was not a professional metaphysician but someone who took his metaphysics seriously. His body and soul talk is not just one, not merely a metaphor for primarily social or political motives. Given the way the poet treats the mentioned categories, the observation of Targoff seems to be entirely plausible.

Sometimes the gender concept is so productive in metaphysical poetry that Donne even groups - within one poem - a large number of so-called subconcepts around it, as in The Indifferent, where the concept of WOMAN changes the poetics of the composition. Here, in the first nine lines, almost all types of the woman nature are concentrated: 
I can love both faire and browne, // Her whom abundance melts, and her whom want betraies, // Her who loves lonenesse best, and her who maskes and plaies, // Her whom the country form'd, and whom the town, // Her who beleeves, and her who tries, // Her who still weepes with spungie eyes, // And her who is dry corke, and never cries; // I can love her, and her, and you, and you, // I can love any, so she be not true. (Booth, 2002, p. 5)

The verbalized concept of WOMAN is metaphorically included in The Message, where the subject of representation becomes the feeling of jealousy of the man to the woman who left him. Dramatic effect and intensity here are achieved by using imperative modality in the first and last lines of the first stanza through their semantic antinomy:

Send home my long strayd eyes to me, // Which $(\mathrm{Oh})$ too long have dwelt on thee; // Yet since there they have learn'd such ill, // Such forc'd fashions, // And false passions, That they be // Made by the // Fit for no good sight, keep them still. // Send home my harmlesse heart againe, // Which no unworthy thought could staine, // But if it be taught by thine // To make jestings // Of protestings, // And crosse both // Word and oath, // Keepe it, for then' tis none of mine. (Booth, 2002, p. 28)

This poem is attractive by the "vibration of the voice" of the character, who either begs his woman not to go, or blame her and suffers, then expresses the notes of despair from the awareness of the unrequited love, when he, with a tragic act of his death, and at the same time of the death of the imaginary world, prefer to put an end to the real world, the world of cruel reality.

In one of the thematically most original poems of Donne, A Lecture upon the Shadow, the poet involves the gender concept into his profound thoughts about the philosophy of love between a man and woman. On a sunny day, the character suggests to his woman to listen to the lecture on that topic. And as parallels to the complexity of the romantic feelings, he brings the dynamics of the shadow, and psychological ambivalence in the relationships of lovers and their shadows.

With the involvement of heterogeneous phenomena, the character manages to create a unique, almost mythological world of the reign of love, which at the same time is real. This provides the internal psychology of the poem. The poet consistently connects the tension of the process of growth of love with the inexorable logic of solar cycles. In the opinion of the character, the shadows that were lagging behind the couple before noon embody the precautions that lovers go for when their feelings are only growing and the fear of being found out in intimacy. But with the growth of real passion, the need to hide in their shadows disappears; they become shorter with the onset of midday hours, namely, with the highest blossoming of love agitation. In such an almost uncontrollable level of consciousness state of love enlightenment, the lovers also lose the real world with all their hesitations, doubts, and fears. Now for them, there is only the world of their feelings and relationships, surreal space, where the universal principle that conquers all the phenomena of reality is clarity, which means that the lovers are on a new level of existence now, they tread onto their shadows:

Stand still, and I will read to thee // A lecture, Love, in Love's philosophy. // These three hours that we have spent, // Walking here, two shadows went // Along with us, which we ourselves produc'd. // But, now the sun is just above our head, // We do those shadows tread, // And to brave clearness all things are reduc'd. // So whilst our infant loves did grow, // Disguises did, and shadows, flow // From us, and our cares; but now' tis not so. // That love has not attain'd the high' st degree, // Which is still diligent lest others see. (Booth, 2002, p. 50)

However, the sense of disenchantment with women, glorified by the poet, finds its embodiment in Donne's poetry no less than glorification. In Song, the poet calls into question the slightest opportunity to meet a faithful, decent woman. He believes that the probability of this is no higher than the likelihood of catching a falling star, realizing the passing of time or hearing the singing of mermaids. Women's loyalty seems so unlikely to a character that, even when he hears the news that an honest and faithful woman is found, he never goes to meet her, because during his trip she has time to deceive a few men:

Goe and catche a falling stare, // Get with child a mandrake roote, // Tell me where all past years are, // Or who cleft the Divels foot, // Teach me to heare Mermaides singing, // Or to keep off envies stinging, // And finde // What winde // Serves to advance an honest minde. // If thou beest born to strange sights, // Things invisible to see, // Ride ten thousand daies and nights, // Till age snow white haires on thee, // Thou, when thou return' st, wilt tell mee, // All strange wonders that befell thee, // And sweare, // No where // Lives a woman true, and faire. // If thou findst one, let mee know, // Such a Pilgrimage were sweet; // Yet doe not, I would not goe, // Though at next doore wee might meet; // Though shee were true, when you met her, // And last, till you write your letter, // Yet shee // Will bee // False, ere I come, to two, or three. (Booth, 2002, p. 9)

Donne's poetry contains such a wide range of genres, viewpoints, and personae, his attitudes towards women shift so quickly, sometimes within a single poem or line, that it is difficult to say precisely what Donne thought, all but impossible to identify an abiding or systematic view of women or gender (Bell, 2006, p. 201). Guibbory (2015) writes that for Donne, "woman is like the warm limbeck, the necessary container - and at the same time the worthless dirt - the 
material that needs to be informed by a masculine soul" (p. 95). But despite isolated, insular location of England and distinctive world outlook of the poets of that time, the woman in metaphysical poetry is not "an island in an island" (McMahon, 2016).

\section{CONCLUSION}

In English metaphysical poetry, gender concepts are objectified at the imagery level by linguistic means, being transformed depending on the author's spiritual and artistic orientations. In John Donne's poems, the concept of WOMAN appears to be pivotal. On the one hand, it is the source of particular author's associations, a crucial means of representation of the worldview and reflection of the ideological principles of the poet; on the other hand, it can be interpreted in several dimensions, while being played a vital role in the communicative structure of metaphysical poetry. It is the ability to operate this gender concept in various ways makes it difficult to interpret the poetry of the Metaphysicals.

Accentuating Donne's metaphysical poetry is being performed precisely through the verbalized concepts which bear the marks of the category of gender. All of them are based on the idea of appealing to the concept of WOMAN: "woman lover", "woman - the supernatural" (The Dreame), "woman - macrocosm" (A Feaver), "woman - disenchantment" (Song), "woman - shadow" (A Lecture upon the Shadow), "woman - soul" (The Ecstasie), "woman - dream", "woman the harbinger of misfortune" (The Message), "woman - nature" (The Indifferent), etc.

These concepts in Donne's metaphysical poetry do not exist in isolation, being in constant interaction with other concepts (MAN, NATURE, TIME, WORLD, etc.). A conceptual metaphor, passing through the stage of imagery, undergoes certain transformations in metaphysical poetry, demonstrating the national specificity of the English verse of the seventeenth century.

Interpretive analysis, carried out within the framework of the gender field, by using English metaphysical poetry, allows us to define the gender concept sphere as one of the most essential means of actualising the linguistic worldview, which is directly formed at the level of mental processes. The shift from contemplative worldview to transpersonal experience actualises a distinctive way of poeticizing which is characterized by a universalistic understanding of the word as a means of comprehending reality and transcending beyond it.

\section{LIMITATIONS \& STUDY FORWARD}

This study makes a scientific contribution to not only literary and cultural studies and philosophy but also to relevant gender studies. The inclusion of metaphysical poetry in research practice in an interdisciplinary field reflects the tendency of modern humanities to expand the boundaries and allows a broad view of the given issues. Gender concepts in poetic discourse are represented as the essential regulators of the author's worldview. The study of other poets of the metaphysical school (George Herbert, Francis Quarles, Richard Crashaw, Henry Vaughan, Andrew Marvell, et al.) from this point of view can be the subject of further scholarly reflection.

\section{ACKNOWLEDGEMENT}

The study was carried out within the research project Theory and Methodology of the Humanities Research under the Conditions of Sociocultural Transformations at the Beginning of the $21^{\text {st }}$ Century (Registration No. 0117U006917). This research received no specific grant from any funding agency in the public, commercial, or non-profit sectors. The author declares no conflict of interest.

\section{REFERENCES}

1. Ahmed, N., \& Wahab, A. (2017). Gender metaphysics in John Donne. National Journal of Multidisciplinary Research and Development, 2(3). 665-666.

2. Barnes, A. W. (2009). Dissecting John Donne's masculinity. In Post-closet masculinities in early modern England (pp. 56-78). Bucknell University Press.

3. Bates, C. (2007). Masculinity, gender and identity in the English Renaissance Lyric. Cambridge University Press. https://doi.org/10.1017/CBO9780511483455

4. Bauer, M., \& Zirker, A. (2013). Sites of death as sites of interaction in Donne and Shakespeare. In J. H. Anderson \& J. C. Vaught (Eds.), Shakespeare and Donne: Generic hybrids and the cultural imaginary (pp. 17-37). Fordham University Press. https://doi.org/10.5422/fordham/9780823251254.003.0002

5. Bednarz, J. P. (2012). Metaphysical wit from Shakespeare to Donne. In Shakespeare and the truth of love (pp. 163-191). Palgrave Macmillan. https://doi.org/10.1057/9780230393325_7

6. Begbie, J. (2018). Redeeming transcendence in the arts: Bearing witness to the Triune God. William B. Eerdmans Publishing Company. https://doi.org/10.1111/moth.12614

7. Bell, I. (2006). Gender matters: The women in Donne's poems. In A. Guibbory (Ed.), The Cambridge Companion to John Donne (pp. 201-216). Cambridge University Press. https://doi.org/10.1017/CCOL0521832373.013 
8. Bell, I. (2010). The art of poetry, the art of courtship: Elizabeth I and the Elizabethan writing culture. In Elizabeth I. The voice of a monarch (pp. 70-30). Palgrave Macmillan. https://doi.org/10.1057/9780230107861_2

9. Benet, D. T. (1994). Sexual transgression in Donne's Elegies. Modern Philology, 92(1). 14-35. https://doi.org/10.1086/392212

10. Bezrukov, A. V. (2017a). Manifestatsiia metafizychnoho svitobachennia v Ekstazi Dzh. Donna [Manifestation of the metaphysical ideology in J. Donne's The Ecstasy]. International Humanitarian University Herald. Philology, 3(1), 128-130.

11. Bezrukov, A. V. (2017b). Metafizychni paradyhmy u tvorchosti pershoho pokolinnia anhliiskykh metafizykiv (Dzh. Donna, Dzh. Herberta, F. Kverlza) [Metaphysical features in the poetry of the first generation of the English Metaphysicals (J. Donne, G. Herbert, F. Quarles)]. Science and Education a New Dimension. Philology, 31(118). 12-15.

12. Blanton, P. G. (2019). Contemplation and Counseling. Inter Varsity Press.

13. Bond, B. (2015). Immanent distance: Poetry and the metaphysics of the near at hand. University of Michigan Press. https://doi.org/10.3998/mpub.8150518

14. Bond, B. (2019). Plurality and the poetics of Self. Palgrave Pivot. https://doi.org/10.1007/978-3-030-18718-7

15. Booth, R. (Ed.). (2002). The collected poems of John Donne. Wordsworth Editions.

16. Breitenberg, M. (1996). Anxious masculinity in early modern England. Cambridge University Press. https://doi.org/10.1017/CBO9780511586231

17. Cavazos-González, G. (2010). Beyond piety: The Christian spiritual life, justice, and liberation. Macmillan Publishers.

18. Cohen, A. C. (2002). A man, a woman, and the insect that consummated their love: Passion and metaphysical conceit in John Donne's "The Flea". American Entomologist, 48(2). 70-71. https://doi.org/10.1093/ae/48.2.70

19. DiPasquale, T. M. (2011). Donne, women, and the spectre of misogyny. In D. Flynn, M. Hester \& J. Shami (Eds.), The Oxford Handbook of John Donne (pp. 678-689). Oxford University Press. https://doi.org/10.1093/oxfordhb/9780199218608.013.0056

20. Dörge, C. (2018). The notion of turning in metaphysical poetry. LIT Verlag.

21. Ellrodt, R. (2000). Seven Metaphysical poets: A structural study of the unchanging Self. Oxford University Press. https://doi.org/10.1093/acprof:oso/9780198117384.001.0001

22. Filo, G. (2019). Gender, Genre, and Donne's "The Flea". Modern Philology, 117(2). $214-232$. https://doi.org/10.1086/705348

23. Gardner, H. (Ed.). (1965). John Donne. The Elegies, and The Songs and Sonnets. Clarendon Press. https://doi.org/10.1093/actrade/9780198118350.book.1

24. Grady, H. (2017). John Donne and Baroque Allegory: The aesthetics of fragmentation. Cambridge University Press. https://doi.org/10.1017/9781108164337

25. Greteman, B. (2010). "All this seed pearl": John Donne and bodily presence. College Literature, 37(3), 26-42. https://doi.org/10.1353/lit.0.0117

26. Guibbory, A. (2015). Returning to John Donne. Ashgate Publishing. https://doi.org/10.4324/9781315606170

27. Hammons, P. S. (2010). Gender, sexuality, and material objects in English Renaissance verse. Ashgate Publishing. https://doi.org/10.4324/9781315254562

28. Harbison, R. (2000). Reflections on Baroque. University of Chicago Press.

29. Hodgson, E. M. A. (1999). Gender and the sacred Self in John Donne. University of Delaware Press.

30. Hudson, V. R. (2019). Baroco: The logic of English Baroque poetics. Modern Language Quarterly. A Journal of Literary History, 80(3), 233-259. https://doi.org/10.1215/00267929-7569598

31. Hutton, S. (1994). Platonism in some Metaphysical poets. In A. Baldwin \& S. Hutton (Eds.), Platonism and the English imagination (pp.163-178). Cambridge University Press. https://doi.org/10.1017/CBO9780511553806.016

32. Lambert, G. (2004). The return of the Baroque in modern culture. Continuum. https://doi.org/10.5040/9781472545954.ch-012

33. Laqueur, T. (2003). Making sex: Body and gender from the Greeks to Freud. Harvard University Press.

34. Legouis, P. (1962). Donne the Craftsman. An essay upon the structure of The Songs and Sonnets. Russell \& Russell.

35. Li, Z., \& Ce, W. (2019). Analysis on the metaphysical conceit in John Donne's poems. International Journal of Humanities and Social Science, 6(5), 95-98. https://doi.org/10.14445/23942703/IJHSS-V6I5P114

36. Lotman, Yu. (1998). Struktura khudozhestvennogo teksta [Literary text structure]. In Ob iskusstve [On Art] (pp. 203-269). Iskusstvo.

37. Marotti, A. (2006). The social context and nature of Donne's writing: Occasional verse and letters. In A. Guibbory (Ed.), The Cambridge Companion to John Donne (pp. 35-48). Cambridge University Press. https://doi.org/10.1017/CCOL0521832373.003

38. McMahon, E. (2016). Islands, identity and the literary imagination. Anthem Press.

39. Mintz, S. B. (2001). 'Forget the Hee and Shee': Gender and play in John Donne. Modern Philology, 98(4), 577-603. https://doi.org/10.1086/493001 
40. Mueller, J. (1989). Women among the Metaphysicals: A case, mostly, of being Donne for. Modern Philology, 87(2), 142-158. https://doi.org/10.1086/391761

41. Netzer, D. (2015). Mystical poetry and imagination: Inspiring transpersonal awareness of spiritual freedom. International Journal of Transpersonal Studies, 34(1-2), 128-143. https://doi.org/10.24972/ijts.2015.34.1-2.128

42. Popova, Z., \& Sternin, I. (2015). Yazyk i natcionalnaia kartina mira [Language and Ethnic Worldview] (4 ${ }^{\text {th }}$ ed.). Direkt-Media.

43. Pound, E. (1991). ABC of reading (reissued). Faber \& Faber.

44. Redpath, T. (Ed.). (2009). The Songs and Sonets of John Donne ( $2^{\text {nd }}$ ed.). Harvard University Press.

45. Reid, D. (2000). The Metaphysical poets. Routledge. https://doi.org/10.4324/9781315841380

46. Riano, N. (2019). A foray into metaphysical poetry with John Donne. The Imaginative Conservative. https://theimaginativeconservative.org/2019/02/foray-metaphysical-poetry-john-donne-nayeli-riano.html

47. Sarangi, I. (2013). The objectification of women in the poems of John Donne. Labyrinth: An International Refereed Journal of Postmodern Studies, 4, 145-148.

48. Saunders, B. (2006). Desiring Donne: Poetry, sexuality, interpretation. Harvard University Press.

49. Stubbs, J. (2008). Donne: The reformed soul. W. W. Norton \& Company.

50. Sullivan, C. (2008). The rhetoric of the Conscience in Donne, Herbert, and Vaughan. Oxford University Press. https://doi.org/10.1093/acprof:oso/9780199547845.001.0001

51. Targoff, R. (2008). John Donne: Body and soul. University of Chicago Press. https://doi.org/10.7208/chicago/9780226789781.001.0001

52. Teskey, G. (2019). The metaphysics of the Metaphysicals. In M. Schoenfeldt (Ed.), John Donne in context (pp. 236-246). Cambridge University Press. https://doi.org/10.1017/9781107338593.025

53. Thommen, B. (2014). The sexual and the spiritual in John Donne's poetry: Exploring 'The Extasie' and its analogues. Inquiries Journal, 6(11). http://www.inquiriesjournal.com/a?id=938

54. Vlasova, T. (2015). Krizis gendernoi identichnosti v narrativakh i diskursakh postmoderna [The crisis of gender identity in the narratives and discourses of postmodernism]. The Proceedings of the National University of Ostroh Academy. Gender Studies, 1, 10-18.

55. Wade, M. R. (2014). Gender matters: Discourses of violence in early modern literature and the arts. In M. R. Wade (Ed.), Gender matters (pp. 5-15). Brill | Rodopi. https://doi.org/10.1163/9789401210232_002

56. Young, R. (2009). Donne's Catholic conscience and the wit of religious anxiety. Ben Jonson Journal, 16(1-2). 57-76. https://doi.org/10.3366/E1079345309000492 